results, it seems required. A highly legalistic interpretation of the Act may, if adopted, be avoided by an equally legalistic device on the part of the insurers. And to the extent that the device is not used, plaintiff insurers will again resort to Congress for relief by private bill, ${ }^{26}$ an insalubrious procedure for which the Tort Claims Act was supposed to supply a speedier and more equitable substitute. ${ }^{27}$

ROBERT B. DONwORTH, JR.†

\title{
LAND UNDER EXCLUSIVE FEDERAL JURISDICTION: AN ISLAND WITHIN A STATE*
}

Certain land areas in the United States are nominally under the exclusive jurisdiction of the federal government. 1 State courts usually dismiss lawsuits when a resident of such an area is a party on the ground that

26. Only those claims which can be prosecuted under the Act are barred from possible Congressional relief through the private law, Pub. L. No. 601, 79th Cong., 2d Sess., $\$ 131$ (Aug. 2, 1946).

27. "Even when the king consents to be sued, some subjects disbelieve." 3 Mooru, Federal Practice 1351 (2d ed. 1948).

t Member of the second-year class, Yale Law School.

* Chaney v. Chaney, 53 N.M. 66, 201 P.2d 782 (1949) ; Hercules Powder Co. v. Ruben, 188 Va. 694, 51 S.E.2d 149 (1949).

1. Exclusive federal jurisdiction arises in two major ways :

(a) When the federal government acquires land in accordance with U.S. Const. Art. 1, §8, clause 17: "The Congress shall have Power To exercise exclusive Lcgislation in all Cases whatsoever, over [the District of Columbia] ...., and to exercise like Aulhority over all Places purchased by the Consent of the Legislature of the State in which the same shall be, for the Erection of Forts, Magazines, Arsenals, dock-Yards, and other needful Buildings." (Italics added.) The phrase "exclusive Legislation" necessarily implies "exclusive jurisdiction," see James, State Tax Commissioner v. Dravo Contracting Co., 302 U.S. 134, 141 (1937); the term "purchased" often includes "condemned," see Arledge v. Mabry, 52 N.M. 303, 313, 197 P.2d 884, 890 (1948). But see TwitTY, TuE Respective Powers of the Federal and Local Governments Within Lands Owned OR Occupied by the United States 20-2 (1944). The state can qualify its consent in any way not inconsistent with the federal purpose. See note $19 \mathrm{infra.}$

(b) When a state cedes to the federal government exclusive jurisdiction over land theretofore owned by the United States without such jurisdiction. See Rupp, Jurisdiclion Over Lands Ozened by the United States Within the State of Washington, 14 WAstr. L. REv. 1, 7 (1939).

Under both of the foregoing headings, exclusive federal jurisdiction is now presumed not to arise unless expressly accepted by the United States. See note 26 infra. The state, moreover, can specifically reserve powers not impairing the use of the land for the designed federal purpose. As for type (b), this right has always been recognized. Fort Leavenworth R.R. v. Lowe, 114 U.S. 525 (1885). Under clause 17, however, the right was denied until 1937 . See note 19 infra. Only the powers specifically reserved by the 
land under exclusive federal jurisdiction is not a part of the state. ${ }^{2}$ And if the subject matter of the suit is outside the jurisdiction of federal courts, a litigant is either left entirely without a forum or caused the delay and inconvenience of bringing an action in a state court remote from his residence.

Two recent cases point up these problems. In Chaney v. Characy ${ }^{3}$ the New Mexico Supreme Court refused to grant a divorce to a resident of the part of Los Alamos under exclusive federal jurisdiction because she was not a resident of the state as required by the divorce statute. Since Mrs. Chaney resided within the borders of New Mexico, no other state had jurisdiction to grant her a valid divorce. ${ }^{5}$ Furthermore, the United States Supreme Court has repeatedly disclaimed federal jurisdiction of divorce, ${ }^{b}$ and there is no statute giving federal courts divorce jurisdiction over residents of federal lands. In short, the New Mexico decision left the Los Alamos resident without a forum unless she became domiciled in another state.

This result is not peculiar to divorce cases. Residents of federal areas may look in vain for a forum in adoption and custody cases since there is no federal jurisdiction of the subject matter and state jurisdiction statutes generally require that either the child or the parents be residents of the state. ${ }^{7}$ Similarly, state courts cannot probate the will of a non-resident who has no property in the state. $\$$ Furthermore, a party suing a federal area resident with no property outside the area can neither satisfy a judgment obtained in a state court ${ }^{9}$ nor invoke federal diversity jurisdiction. ${ }^{19}$

states can be exercised by them. Collins v. Yosemite Park \& Curry Co., 304 U.S. 518 (1938).

2. For a doctrinal escape from this conclusion, see p. 1406 infra.

3. '53 N..M. 66, 201 P.2d 7\$2 (1949).

4. "The plaintiff in action for the dissolution of the bonds of matrimony must have been an actual resident, in good faith, of the state for one [1] year next preceding the filing of his or her complaint. . ." N.M1. St.1T. ANn. \$25-704 (1941).

5. See Williams v. North Carolina, 325 U.S. 226, 229 (1945); Jennings v. Jennings, 36 So.2d 236, 237 (Ala. 1948). See MLadnen, Doarestic Relatroxis \$93 (1931).

6. See, e.g., Barber v. Barber, 21 How. 5\&2, 584 (U.S. 1858); Ohio ex rel. Popovici v. Alger, 280 U.S. 379, 383 (1930).

7. The Supreme Court has held that "[t]he whole subject of domestie relations of husband and wife, parent and child, belongs to the laws of the states and not to the laws of the United States." In re Burrus, 136 U.S. 586, 593-4 (1890).

Where state statutes include a residence requirement, the court has no adoption jurisdiction over a non-resident. Heirich v. Howe, 50 N.MI. 90, 171 P.2d 312 (1946). A guaraian can be appointed only by a court within whose jurisdiction the child either resides or owns property. MLADDEN, op. cit. sitpra note 5, at 469 .

8. For a discussion of state jurisdictional requirements see Atsmso:;, WIuL 431-4 (1937). And Federal courts have no jurisdiction of purely probate matters. Farrell v. O'Brien, 199 U.S. S9 (1905).

9. State courts ordinarily do not have the power of attachment within foderal areas, Foley v. Shriver, 81 Va. 568 (1886) ; Brooks Hardware Co. v. Greer, 111 Me 78, \$7 Atl. 889 (1913) ; and execution traditionally follows hand in hand with attachment. But it would appear that a state can levy execution if concurrent jurisdiction is reserved. See note 19 infra.

10. The diversity jurisdiction statute provides that the federal district courts shall 
Even where the doctrine does not have the effect of denying the litigant a forum, it may impose a considerable burden. In another recent case, Hercules Powder Company v. Ruben, ${ }^{11}$ the defendant Delaware corporation had operated a munitions factory within the borders of Virginia on land under exclusive federal jurisdiction. When the factory ceased operation, Ruben brought suit in the state court for the county which contained the federal area seeking to obtain termination pay allegedly due under his employment contract. But the Virginia Supreme Court dismissed the complaint. It held that this area was not part of the state and therefore the cause of action did not arise in the county as required by the venue statute. ${ }^{12}$ Although Ruben has access to several more remote forums, ${ }^{13}$ the instant decision caused him delay, inconvenience and the loss of a local jury. And Ruben was not the only one harassed. His appeal was a test case for about 150 corresponding claims. ${ }^{14}$

The refusal of state courts to assume jurisdiction results from the belief that the existence of exclusive federal jurisdiction necessarily denies the state any authority. ${ }^{15}$ Courts also have argued that since federal area residents were not subject to state taxation, they were not entitled to privhave original jurisdiction of all civil actions where the matter in controversy is morc than $\$ 3000$ and is between "citizens of different states." For the purposes of this section, "states" is defined as including the Territories and the District of Columbia. 28 U.S.C. \& 1332 (1948). Thus federal areas are not included. Although the Constitution provides that "[a]11 persons born or naturalized in the United States, and subject to the jurisdiction thereof, are citizens of the United States and of the State wherein they reside" U.S. Const. AmEnd. XIV, $\$ 1$, there is a clear distinction between citizenship of the United States and citizenship of a state. Slaughter-house Cases, 16 Wall. 36, 73 (U.S. 1872). One ceasing to reside in a state ceases to be a citizen of that state even though retaining United States citizenship. Hammerstein v. Lyne, 200 Fed. 165 (W.D. Mo. 1912).

11. 188 Va. 694, 51 S.E.2d 149 (1949).

12. Civil actions against a corporate defendant may be brought only in a county where (a) the corporation's principal office is, or (b) its president or chief officer resides, or (c) its statutory agent resides, or (d) it has any estate or debts owing to it, or (c) the cause of action arose. VA. CoDE $\$ \S 6049,6050$ (1942). The question in the Hcrcules case concerned only the last alternative, because uncontested facts clearly indicated that none of the first four conditions was satisfied in Pulaski County, where the suit was brought. Transcript of Record, pp. 3-5, Hercules Powder Company v. Ruben, 188 Va. 694, 51 S.E.2d 149 (1949).

13. It would appear that Ruben can get a hearing on the merits either in Richmond, Va., where the statutory agent for the Hercules Powder Company (the Secretary of the Commonwealth) resides, id. at 3, or, since Hercules is a Delaware Corporation, in the courts of that state.

14. Appellee's Petition for Re-hearing, p. 2, Hercules Powder Company v. Ruben, 188 Va. 694, 51 S.E.2d 149 (1949).

15. State courts seem to have been heavily impressed by the following statement of the Supreme Court:

"When the title is acquired by.purchase by consent of the Legislatures of the States, the federal jurisdiction is exclusive of all State authority. This follows from the declarttion of the Constitution that Congress shall have 'like authority' over such places as it has over the district which is the seat of government; that is, the power of 'exclusive legislation in all cases whatsoever.' Broader or clearer language could not be used to 
ileges accorded taxpayers. ${ }^{16}$ But the factual basis for the earlier decisions no longer exists. Within the last thirteen years Congress has given the states power to enforce their workmen's compensation laws ${ }^{17}$ and to collect sales, use, gasoline and income taxes. ${ }^{18}$ And today the Supreme Court recognizes the power of a state to reserve in federal areas whatever authority is not inconsistent with the national purpose, even if the practical result is concurrent jurisdiction. ${ }^{19}$ Furthermore, to deny federal area residents a state forum seems particularly inequitable in view of the fact that they are now subject to state taxation. ${ }^{20}$

exclude all other authority than that of Congress." Fort Leavenworth R.R. v. Lowe, 114 U.S. 525, 532 (1885).

For applications of the principle, see, e.g., Lowe v. Lowe, $150 \mathrm{MId}$. 592, 600, $133 \mathrm{Atl}$. 729,733 (1926) (no divorce in state court); Sinks v. Reese, 19 Ohio St. 306, 316-17 (1869) (no vote in state election). Commonwealth v. Clary, 8 MIass. 72, 75 (1811) (state liquor laws not applicable).

16. See Lowe v. Lowe, 150 MId. 592, 601, 133 Atl. 729, 733 (1926) ; Sinlss v. Reese, 19 Ohio St. 306, 316 (1S96). Commonwealth v. Clary, 8 Afass. 72, 76 (1S11).

17. 49 Stat. 1938 (1936), 40 U.S.C. $\$ 290$ (1946). Capetola v. Barelay White Co. 139 F.2d 556 (3d Cir. 1943).

18. 54 Stat. 1059 (1940), 4 U.S.C. $\$ \$ 12-1 \$$ (1946).

19. When the federal government owns an area, but does not have exclusive jurisliction over it, the state can exercise any power which does not interfere with the free and adequate use of this area for federal governmental purposes. Twirsy, op. cif. suspra note 1, at 2. Exclusive federal jurisdiction can arise only with the consent of the state. See note $2 S$ infra. States usually give the requisite consent readily besause of possible federal pressure in the form of reduced grants in aid and public works; but they oiten qualify their consent because they wish to retain some or all of the powers which they could have exercised had the federal government merely used the area without acquiring exclusive jurisdiction. These qualifications are upheld if limited to powers which do not intericre with the federal purpose. See note 1 susra.

But until 1937 it was generally supposed that no qualifications (beyond the power to serve process) were permissibie with the consent under clause 17. A state could theorctically avoid this pitfall and retain its powers simply by reiusing consent whenever the federal government bought or condemned land within the state. To correct this situation (and make it unnecessary for the state to antagonize the foderal government), the Supreme Court held that, despite contrary dicta in United States v. Cornell, 25 Fed. Cas. No. 14867, at 649 (C.C.D.R.I. 1819), and in Fort Leavenworth R.R. v. Lowe, 114 U.S. 525, 533-4 (1855), the state can qualify its consent to federal acquisition of exclusive jurisdiction under clause 17. James, State Tax Commissioner v. Dravo Contracting Co, 302 U.S. 134 (1937). TwITTY, op. cit. supra note 1, at 9. In this case such broad state powers were consistent with the federal purpose that a state reservation of concurrent jurisdiction was upheld. Said Mr. Chief Justice Hughes: "The possible importance of reserving to the state jurisdiction for local purposes which involve no interference with the performance of governmental functions is becoming more and more clear as the activities of the government expand and large areas within the states are acquired." 302 U.S. at 148.

Courts have applied the doctrine that federal areas are not part of the state only in those areas acquired pursuant to clause 17. See note 15 sisfra. But since the Supreme Court now recognizes equal reservations of power in each situation, it appears that clause 17 areas should be classed with cession areas as parts of the state.

20. See Kiker v. Philadelphia, 3\$6 Pa. 624, 630-1, 31 A.2d 289, 293-4 (1943) ; Twrтr;; op. cit. supra note 1 , at 42 . 
To vitiate the practical hardships which resulted from the denial of state jurisdiction, some courts at an early stage developed a "rule of necessity" which recognized state judicial power whenever a litigant would otherwise be left without a forum. ${ }^{21}$ The rule is an application of the established principle that whenever jurisdiction over an area is transferred from the state to the federal government, the state laws at the time of cession continue in force to protect the private rights of individuals residing within the area. ${ }^{2 z}$ But only a few courts recognize the rule, ${ }^{23}$ and even they have never applied it to the problem of the Hercules case where the litigant, while not denied a forum, was seriously inconvenienced.

In matters not affecting the operation of the national government, there is no sound reason why federal area residents should not have the same rights, immunities, and responsibilities as residents of the surrounding state. ${ }^{24}$ Congress has often followed this policy of uniformity, ${ }^{26}$ but has not carried it to completion. Given the strength of the doctrine relied upon in the Chaney and Hercules decisions and the unwillingness of courts to apply the rule of necessity, any further advance in the policy of uniformity seems dependent on additional federal legislation.

In nonmilitary areas, such as housing projects, factories, and parks, where the federal government often has exclusive jurisdiction which it does not need, ${ }^{26}$ a simple reform would be the retrocession of jurisdiction to the

21. Divine v. Unaka National Bank, 125 Tenn. 98, 140 S.W. 747 (1911); Barrett v. Palmer, 135 N.Y. 336, 31 N.E. 1017 (1892), aff'd on other ground, Palmer v. Barrett, 162 U.S. 399 (1896). See Chief Justice Bond dissenting in Lowe v. Lowe, 150 Md. 592, 602, 133 Atl. 729, 733 (1926).

22. State statutes and common law both continue in force. Stewart \& Co. v. Sadrakula, 309 U.S. 94, 100 (1940) ; Chicago, Rock Island \& Pacific R.R. v. McGlinn, 114 U.S. 542, 546 (1885). Of this principle Mr. Justice Reed said in the Sadrakula case: "This assures that no area however small will be left without a developed legal system for private rights." 309 U.S. 94, 100 (1940).

23. For cases rejecting the rule see, e.g., Chaney v. Chaney, 53 N.M. 66, 201 P.2d 782 (1949) ; Lowe v. Lowe, 150 Md. 592, 133 Atl. 729 (1926).

24. See Rupp, supra note 1 , at 29.

25. E.g., the Assimilative Crimes Act, 18 U.S.C. $\$ 13$ (1948); Tw1TTY, op. cit. supra note 1 , at 44-6. The statute makes the federal criminal law in a federal area identical with the criminal law of the surrounding state. The Buck Act, see note 18 supra, empowers the states to collect their sales, use, gasoline and income taxes in federal areas. State law on a right of action for wrongful death has been extended to federal areas, 45 STAT. 54 (1928), 16 U.S.C. $\$ 457$ (1946), and state workmen's compensation laws also apply. See note 17 sipra.

26. Much unnecessary jurisdiction arose from the fact that exclusive federal jurisdiction was presumed accepted upon federal purchase of land with the consent of the state for a purpose specified in U.S. Const. Art. I, \$8, clause 17. Fort Leavenworth R.R. v. Lowe, 114 U.S. 525, 528 (1885) ; Benson v. United States, 146 U.S. 325, 330 (1892). This was curtailed somewhat by Congress in 1940. A bill was passed providing that administrative officers could make whatever jurisdiction arrangements seemed desirable, and that until the United States accepted jurisdiction over lands acquired, it should be conclusively presumed that no such jurisdiction had been accepted. 54 STAT. 19, 1083 (1940), U.S.C. $\$ 255$ (1946); Adams v. United States, 319 U.S. 312 (1943). 
state. ${ }^{27}$ But national security often demands that the state legislature have no authority in areas such as forts and secret developments. ${ }^{33}$ For these areas exclusive federal jurisdiction is still required." Uniformity could here be achieved by legislation stating that land over which the United States has exclusive jurisdiction should be deemed part of the state for local purposes not conflicting with national purposes. ${ }^{33}$ Such a Congressional reversal of judicial doctrine would usually make state court process, attachment, garnishment, and execution effective within the area, and would allow people living in federal areas to be residents and citizens of a state. To avoid an interpretation which might limit the exclusive legislative power of Congress over these areas, the enactment should include a provision that state legislative authority be deemed suspended after cession except as specifically restored by Congress. ${ }^{31}$ Under such a statute, the more distressing aspects of non-uniformity caused by the doctrine that federal areas are not part of a state would be eliminated.

Thus unnecessary exclusive federal jurisdictions no longer arises, but those instances in which it came into existence automatically must still be remedied. Sec, e.g., Johnson v. IIorrill, 20 Cal.2d 446, 126 P.2d 873 (1942); State $e x$ rel. Parker v. Corcoran, 155 Kan. 714,128 P.2d 999 (1942) ; TwITTY, op. cit. sufra note 1, at 55.

When the federal government not only does not need exclusive jurisdiction but also ceases to use the area for a federal purpose, the exclusive federal jurisdietion automatically terminates. S.R.A., Inc. v. MIinnesota, 327 U.S. 558 (1946).

27. Two months after the decision in Chaney v. Chaney, Congress retroceded to New Mexico jurisdiction over parts of Los Alamos. Pub. L. No. 14, Slst Cong, 1st Sess. (Mfar. 4, 1949). This legislation was requested by the Atomic Energy Commission on Aus. 3, 1948 , to eliminate the handicap on local government resulting from the lacl: of clarity in the jurisdictional status of Los Alamos. The Commission had made worlable arrangements at both Oak Ridge and Hanford without acquiring exclusive federal jurisdietion. H.R. Rep. No. 31, 81st Cong., 1st Sess. 2 (1949).

2S. It was this demand which apparently prompted the inclusion of Art. I, $\$ \&$, clause 17 in the Constitution. See note 1 supra; The Fenenalist, No. 43 (MIadison). The requirement of state consent was included to prevent the use of the power to enslave a state by buying up its territory. Mladison, Joursal of tHe Federal Co:ive:itios: 662 (edited by E.H. Scott 1893).

29. Since exclusive federal jurisdiction is not desired over the atomic energy projects, see note 27 supra, it appears that the actual need for such jurisdiction does not go much beyond areas under military law. See TwrTx, op. cit. supra note 1, at 10.

30. See note 19 supra.

31. The proposed legislation still leaves one glaring element of non-uniformity: the civil law applicable within a federal area is the state law at the time of cession. Sce note 22 supra. To keep the federal area law up to date, an Assimilative Civil Law Act, comparable to the Assimilative Crimes Act, see note 25 sapra, is needed. Rupp, sispra note 1, at 13; Comment, 37 Yale L. J. 796, 803 (1923). Since the federal government might want to omit certain state laws, it seems more feasible to use assimilative statutes than simply to allow the state substantive law to apply as such. 